PAEDAGOGIA ChRISTIANA

I/21 (2008) - ISSN 1505-6872

Jarostaw Michalski*

Torun-Olsztyn

\title{
Edukacja religijna a epoka ponowoczesna
}

Okres ponowoczesny związany z szybkimi przemianami ustrojowymi, obejmującymi zarówno sferę polityczną, społeczno-ekonomiczną, edukacyjną i cywilizacyjna, postawił przed człowiekiem wiele skomplikowanych problemów dotyczących jego egzystencji. Dzisiaj nie ulega już wątpliwości, że nie jesteśmy przygotowani na nieprzejrzystość, ambiwalencję świata i porażki. Współczesny człowiek narażony jest na ciągły stres i poczucie braku wpływu na własne życie. Dobrym przykładem są choćby - ostatnie, tragiczne wydarzenia, związane z katastrofą, jaka wydarzyła się w hali targowej w Katowicach, i śmiercią kilkudziesięciu osób. Każdego dnia człowiek staje wobec konieczności wyborów, które są tym trudniejsze, bo często nie znajdują wsparcia w przeszłości, w przykładach osób najbliższych i sam musi tworzyć własną tożsamość na „ruchomych piaskach”. Wszystko to staje się szczególnego rodzaju powodem, by wychowanie, a przede wszystkim wychowanie religijne, uczynić przedmiotem poważnego namysłu, zwłaszcza w kontekście wszechogarniającego pluralizmu (historycznego, społeczno-kulturowego, etc. $)^{1}$.

Niniejszy artykuł jest próbą zastanowienia się, z pozycji pedagoga, nad nowym rozumieniem wychowania religijnego w naszej sytuacji historycznej, jest próbą odpowiedzi na pytanie, jak współcześnie powinno wyglądać wychowanie

${ }^{*}$ Ks. dr hab. Jarosław Michalski, prof. UWM i UMK, kierownik Zakładu Filozofii i Socjologii Edukacji na Uniwersytecie Warmińsko-Mazurskim w Olsztynie oraz Pracowni Pedagogiki Filozoficznej i Chrześcijańskiej na Uniwersytecie Mikołaja Kopernika w Toruniu.

${ }^{1}$ Por. Z. Melosik, Modernizm i postmodernizm we wspótczesnym dyskursie humanistycznym: konfrontacje i kontrowersje, w: J. Gnitecki (red.), Pedagogika jako formacja intelektualna refleksji we wspótczesnym dyskursie humanistycznym, Poznań 2005, s. 21-50; K. Szafraniec, Człowiek wobec zmiany społecznej, Warszawa 1990; R. Szulz, Szkoła. Instytucja-system-rozwój, Toruń 1995; J. Żebrowski (red.), Edukacja a spoteczeństwo obywatelskie, Gdańsk 1995. 
religijne. Wychowanie religijne, które osobiście określam jako „wychodzące od człowieka i zorientowane na człowieka" czyli takie, w którym centralnym momentem procesu wychowawczego jest człowiek jako osoba. Wychowanie religijne, które byłoby szansą na jego integralny rozwój.

Założenia takie przekreślają oczywiście, jako z gruntu fałszywe i nieuzasadnione, traktowanie relacji między religią a wychowaniem, a rozwojem człowieka, jako alternatywy czy choćby dylematu. Wskazuje na perspektywę religijną oraz pozwala na konstruktywną dyskusję o możliwych drogach stawania się człowiekiem. Często bowiem we współczesnej myśli o wychowaniu pojawia się owa alternatywa, według której wprowadzenie do wychowania religii miałoby oznaczać rezygnację z programu wspierania rozwoju człowieka. Jak zauważa Katarzyna Olbrycht,

jeśli „wspieranie rozwoju” uznać - w myśl współczesnych poglądów pedagogicznych, a także zgodnie z filozofią antywychowania - za alternatywę dla ,wychowania tradycyjnego", opartego na przemocy wewnętrznej i zewnętrznej, religia (kojarzona z wychowaniem) i nowoczesne podejście do pracy z dzieckiem stanowiłyby dwa przeciwstawne bieguny stosunku do człowieka i jego rozwoju. Religia, kojarzona przez ideologów nowoczesnego wychowania z przymusem kulturowo-obyczajowym, bezwolnością, zgodą na represyjność, ćwiczeniem postaw adaptacyjnych, akceptacją irracjonalności, rzeczywiście byłaby nie do pogodzenia z wyzwoleniem w człowieku motywacji do rozwoju różnych jego potencjałów, do uwalniania się od presji zewnętrznej i wewnętrznej, do walki o własny autentyzm. Dyskusja, bardziej lub mniej jawnie zakładająca taką interpretację ścierających się stanowisk, zafałszowuje rzeczywistą sytuację i wymusza sztuczne wybory racji ${ }^{2}$.

Celem wychowania religijnego „wychodzącego od człowieka i na niego zorientowanego", prowadzonego zarówno przez społeczeństwo, jak i przez pojedynczego wychowawcę, jest pomoc w kształtowaniu ,prawdziwych przekonań religijnych podtrzymywanych i wspieranych naturalnymi i autentycznymi motywacjami”. Chodzi tu o zaoferowanie wychowankom konkretnej pomocy umożliwiającej krok po kroku dokonanie ostatecznych decyzji, które staną się bazą ich życia, fundamentem ich integralnego rozwoju.

Wydaje się bowiem, o czym pisze m.in. włoski psycholog i pedagog Franco Imoda, iż ,jedynie wiara, która przeszła przez krytykę głębokich motywacji, ma możliwość przetrwania i wspierania rozwoju człowieka; jedynie chrześcijaństwo oparte na głębokich przekonaniach bez uwzględniania tylko zwykłych uzewnętrznianych tradycji lub masowych manifestacji, ma szansę przeżycia"3. Tak rozumiane wychowanie bazuje z jednej strony na niepodważalnym fakcie istnienia religii oraz na szczególnej relacji między nią

${ }^{2}$ K. Olbrycht, Religia a wspieranie rozwoju czlowieka, w: Z. Zdybicka (red.), Religia a sens bycia człowiekiem, Lublin 1994, s. 103-104. Por. J. Michalski, Edukacja i religia jako źródta rozwoju egzystencjalno-kognitywnego. Studium hermeneutyczno-krytyczne, Torun 2004, s. 21-42.

${ }^{3}$ F. Imoda, Sviluppo umano, psicologia e mistero, Alessandria 1993, s. 13. 
a osobą ludzką i pozwala na wskazanie dróg (metod) wychowawczych, które do niego prowadzą.

Całość rozważań zawarta jest w dwóch zasadniczych częściach. W pierwszej części ukazany zostanie problem szczególnej relacji między religią a osobą ludzką. Na bazie tych rozważań przedstawione zostaną, w części kolejnej, obszary oddziaływań wychowawczych, kształtujących dojrzałą religijność, która pozwoli być fundamentem integralnego rozwoju człowieka.

\section{Religia a osoba ludzka}

Relację między religią a osobą ludzką można by określić jako relację zachodzącą między autorytetem Boga a wolnością człowieka. Dla rozstrzygnięcia tego zagadnienia trzeba bliżej określić charakter autonomii sumienia czyli wolności człowieka. Skoro sumienie jest sądem rozumu, a więc aktem poznawczym stwierdzającym prawdę o dobru, które należy czynić, to w samej istocie sumienia zawsze jest odniesienie do prawdy. Autonomia sumienia nie jest więc absolutną twórczością w zakresie ustalania powinności działania i jego ukierunkowania. Tworzy się raczej poprzez właściwe odniesienie osoby ludzkiej do prawdy o sobie i otaczającej ją rzeczywistości. Prawda ta musi być uwzględniana w moralnym działaniu człowieka, będącym działaniem w świecie osób i rzeczy ${ }^{4}$.

Z sumieniem człowieka nierozerwalnie związana jest jego moralność. Jej analiza na płaszczyźnie czysto neutralnej ujawnia konieczność odniesienia osoby ludzkiej do Boga. Dzieje się to wówczas, gdy chcemy wskazać na ostateczne podstawy ontyczne norm moralnych czy odpowiedzialności człowieka. Religia zmienia perspektywy. Od razu ustawia człowieka do Boga. Jeśli przez religię rozumiemy stosunek człowieka do Boga, który opiera się w człowieku na jego naturze osobowej, a więc rozumnej i wolnej, to religia jest czymś istotowo osobowym i ze swej natury nie powinna naruszać charakteru życia moralnego, świadomego i wolnego, kierowanego i ocenianego przez akt sumienia ${ }^{5}$.

W nowej relacji człowieka do Boga, jaką ujawnia religia, obowiązuje ta sama zasada, jaka obowiązuje w całym życiu moralnym człowieka. Jest nią zasada posłuszeństwa w sumieniu. Można więc powiedzieć, że każdy akt religijny jest aktem moralnym, osobowym, ludzkim, a autonomia sumienia kształtowana jest tu także poprzez relację do prawdy ${ }^{6}$.

\footnotetext{
${ }^{4}$ K. Wojtyła, Osoba i czyn, Kraków 1969, s. 163.

${ }^{5}$ Por. tamże; T. Styczeń, Solidarność wyzwala, Lublin 1993, s. 29-56; tenże, Gewissenautonomie und Norm, w: Busse - Umkehr Formen der Vergebung. Referate der ,Internationalen Theologischen Sommerakademie 1991 der Linzer Priesterkreises in Aigen, Steyr 1992, s. 191-218.

${ }^{6}$ Por. Z. Zdybicka, Religia i religioznawstwo, Lublin 1992, s. 202nn; J. Michalski, dz. cyt., s. $135-136$.
} 
Religia w tym zakresie wnosi do życia człowieka dwa istotne momenty:

- ukazuje nowe dziedziny rzeczywistości, przez co poszerza domenę prawdy;

- suponuje nowy charakter afirmacji prawd, które nie są poznawane wprost, a dostępne są jedynie na mocy zawierzenia autorytetowi Boga - na mocy wiary?

Jeśli autonomia sumienia, a w konsekwencji autonomia osoby ludzkiej, jej wolność, buduje się w relacji do prawdy i jeśli człowiek buduje swoje postępowanie opierając się na poznaniu, to im lepiej poznaje, im bliższy jest prawdy o sobie i rzeczywistości, tym jest wolniejszy. W tej perspektywie religia nie tylko nie zagraża autonomii sumienia i wolności człowieka, lecz ją poszerza.

Religia wskazuje więc na nowe horyzonty życia ludzkiego, poszerza dziedzinę ludzkich możliwości i wolnych decyzji. Jeśli więc obecnie tak wiele mówi się o ograniczeniu człowieka przez religię, to wynika to często z nieznajomości prawdziwych dróg wolności, a może płynąć także z pewnych deformacji w myśleniu człowieka czy praktykowaniu religii ${ }^{8}$.

Religia rozważana od strony człowieka nie ogranicza się tylko do więzi indywidualnej ,ja-Ty”. Człowiek bowiem swój związek z Bogiem przeżywa społecznie, wspólnotowo. Tak jak w wymiarze jednostkowym związek osoby ludzkiej z Bogiem przyczynia się do jej personalizacji, tak też w wymiarze społecznym do jej socjalizacji. W tym znaczeniu społeczne przeżywanie więzi z Bogiem jest socjotwórcze. Stwarza więc nowe relacje interpersonalne, cementuje religijny byt społeczny, czyni go wspólnotowym podmiotem wobec Boga. Określa też jego bytowanie, możliwości i warunki społecznego stawania się, rozwoju i dopełnienia. Wyznacza ostateczny cel wszelkich aspiracji, dazżeń ludzkich i działań. Tym samym czyni je bardziej sensownymi, ukazując finalne spełnienie się bytu społecznego, osoby społecznej, którą tworzy i buduje religia9.

Przeżywana przez człowieka więź z Bogiem, zarówno w wymiarze indywidualnym, jak i społecznym, chociaż koncentruje się na intymnej sferze wewnętrznej, to jednak nie tylko do niej się sprowadza. Religia ma też swój zewnętrzny wyraz i kształt. Inspiruje przez swoją zewnętrzność do twórczych działań osobowych i społecznych, do doskonalenia się, co znajduje swój wyraz w tworzeniu wartości osobowych i ludzkich o charakterze religijnym, w przemianie życia, współuczestniczeniu w kreatywnej i zbawczej działalności Boga. W tym znaczeniu religia jest wartością niezbywalną w życiu człowieka i społeczności ludz$\operatorname{kiej}^{10}$. Religia jest więc rzeczywistością specyficzną i oryginalną. Nie można jej

${ }^{7}$ Por. tamże; R. Cipriani, La religione diffusa, Roma 1988.

${ }^{8}$ Por. E. Ciupak, Religia i religijność, Warszawa 1982, s. 39nn; A. Exeler, Religiöse Erziehung als Hilfe zur Menschwerdung, München 1982; J. Michalski, Wartości w procesie wychowania. Znaczenie i konieczność, Forum Oświatowe 1 (32), 2005, s. 47-69.

${ }^{9}$ Por. F. Garelli, Forza della religine e debolezza della fede, Bologna 1998, s. 86nn.

${ }^{10}$ M. Rusecki, Istota i geneza religii, Warszawa 1989, s. 144. 
sprowadzić ani do poszczególnych działów kultury, ani do niej samej. Pozostaje w rozlicznych związkach z całą rzeczywistością doczesną, którą przenika, w której się wyraża, w której nie da się zamknąć. Posiada wymiar historyczny, łączy ludzkie z boskim, człowieka z Bogiem. Koncentruje się na osobie ludzkiej, przejawia się i wyraża w jej postawie i działaniach. Jednakże nawet i w tym wymiarze, chociaż jest w znacznym stopniu zobiektywizowana, dostępna do badań, to i tak jawi się jako rzeczywistość tajemnicza, misteryjna, głęboka, tak jak jest nią osoba ludzka, nie do końca poznawalna w swoich wyborach, dążeniach, postawie, życiu.

Ten aspekt religii uwidacznia się szczególnie, gdy rozpatruje się jej stronę przedmiotową, którą stanowi Bóg. Jakkolwiek manifestuje On swą obecność w historii i wezwaniu skierowanym do człowieka w znakach, staje się osnową życia religijnego człowieka, to i wówczas nie jest poznawany do końca, w głębi Jego bytu i wielkości. W związku z tym religia jawi się jako rzeczywistość misteryjna łączności człowieka z Bogiem.

W tym kontekście wiele aktualnie funkcjonujących wcześniej definicji religii jest nieuprawnionych, gdyż zakładają one, że w sposób naukowy, empiryczny można całkowicie poznać i wyjaśnić fenomen religii. Wadliwe są zwłaszcza redukcjonistyczne próby jej ujęcia. Nie zakładają one bowiem rozumienia religii jako osobowej więzi człowieka z Bogiem, lecz podkreślają wytwory człowieka, a te nie mogą stanowić religii ${ }^{11}$.

\section{Wychowanie religijne szansą na integralny rozwój czlowieka}

Obecnie coraz częściej poszukuje się uniwersalnego sposobu wychowania, służącego integralnemu rozwojowi osoby ludzkiej. Doświadczenie pokazuje bowiem, że zarówno wychowanie jednostki do zachowania określonych form postępowania przez ćwiczenie i powtarzanie różnych czynności, ani wychowanie polegające na przyjęciu określonych postaw i wartości, ani wreszcie autorytatywna postawa wychowawcy, która zabija inicjatywę i samodzielność wychowanka, dziś już nie zadowalają i często okazują się niewystarczające.

Niewątpliwie jedną z propozycji rozwiązywania problemu jest wychowanie religijne. Chcąc jednak odpowiedzieć na pytanie, jak wychowywać i do czego wychowywać, należałoby przedtem zastanowić się, kim jest człowiek jako przedmiot wychowania.

Jest z pewnością osobą, podmiotem mówienia, wyrażania się, autokreacji, doświadczania, odniesienia, przeżywania. Jest czymś niepowtarzalnym gdyż posiada określoną i jedyną swego rodzaju tożsamość, identyczność. Cechuje go naturalne odniesienie do otaczającej rzeczywistości, do samego siebie i wartości najwyższej, tj. Boga. Wynika stąd, że w procesie wychowania powinno się

11 Por. Z. Zdybicka, Religia i religioznawstwo..., s. 199nn. 
uwzględniać wszystkie wymiary osobowości człowieka: fizyczny, psychofizyczny i duchowy. Podstawą wychowania będzie zatem nie tylko kształtowanie człowieka obejmujące wymienione strefy ale przede wszystkim pomoc i wspieranie jego dynamicznego rozwoju z uwzględnieniem naturalnych predyspozycji, uzdolnień, talentów, wiedzy. W kontekście wychowania religijnego będzie to też rozwój predyspozycji będących wynikiem wartości nadprzyrodzonych. Zatem wysiłek ludzki dotyczący wszechstronnego wychowania powinien w tym przypadku być wspierany łaską bożą (pochodzącą od Boga). Wychowanie religijne, wiara i właściwy tylko jej system wartości, może i często odgrywa rolę w rozwoju, wychowaniu i formowaniu postaw wychowanka względem siebie, świata $\mathrm{i}$ innych.

Całościowe spojrzenie na wychowanie wymaga uwzględnienia najistotniejszych jego elementów składowych, tj. religijności i moralności. Religijność jest najczęściej definiowana jako indywidualny i subiektywny stosunek człowieka do Boga, regulowany określonymi nakazami, prawdami, twierdzeniami wynikającymi z założeń danej religii. Dojrzała forma religijności ułatwia każdemu człowiekowi prawidłowy rozwój osobowości, określenie relacji do transcendencji, do innych osób, do samego siebie i całego otaczającego świata, stąd ma tak istotny wpływ na kształt wychowania ${ }^{12}$.

Każdy człowiek tworzy sobie własną religijność, uzależnioną od własnych potrzeb, przy współudziale różnych sfer swojego życia, tj. rozumu, woli, emocji itp. Dlatego też m.in. nie jest ona jednakowa dla wszystkich ludzi. Na kształt religijności wpływa również całe dziedzictwo kulturowe, znaki, symbole, doświadczenia, zachowania wypływające $\mathrm{z}$ relacji do tego co transcendentne, co nie jest też dostępne bezpośredniemu poznaniu ${ }^{13}$. A wszystko to dokonuje się głównie w procesie wychowania, podczas którego istotną rolę odgrywają przyjęte przez środowisko czy instytucje religijne pojęcia, a przede wszystkim koncepcja bóstwa. Wydaje się jednak, iż w dojrzałości religijnej szczególnego znaczenia nabiera indywidualne doświadczenie związane z różnymi etapami wzrostu. Można tu wymienić następujące etapy:

- dzieciństwo (do 12 r. życia),

- młodość (12-16 r. życia i 16-24 r. życia),

- dojrzałość (25-60 r. życia),

- starość (po 60 r. życia).

Najważniejszym czynnikiem warunkującym prawidłowy rozwój dojrzałości jest oczywiście atmosfera życia rodzinnego, miłość, wzajemne zaufanie,

${ }^{12}$ Por. Z. Chlewiński, Dojrzałość, osobowość, sumienie, religijność, Poznań 1991, s. 85nn; W. Piwowarski, Religia jako wartość wspólna i osobowa, Przegląd Humanistyczny 1994, nr 5 (38), s. 53-61; R. Köcher, Die Entwicklung von Religiosität und Kirchlichkeit seit dem Zweiten Weltkrieg bis heute, Diakonia 1988, nr 19, s. 35-39.

${ }^{13}$ Por. F. Heiler, Le religioni dell'umanità, Milano 1985; Z. Ziółkowski, Z zagadnień dojrzatości religijnej, Znak 210/1971, s. 1587-1594; Z. Płużek, A. Jacyniak, Świat ludzkich kryzysów, Kraków 1996, s. 47-49. 
autentyczne przeżycia religijne, w których dziecko uczestniczy. Bezkrytyczne przyjmowanie tego, co się wcześniej przyjęło od rodziców, przechodzi jednak w konfrontację z chwilą rozwoju zdolności myślenia abstrakcyjnego i rozwoju umysłowego. Jest to pierwszy symptom wejścia w nowy etap dojrzałości religijnej. Jednakże pełna niezależność nie tylko myślenia, ale i działania pojawia się w wieku 16-18 lat. Młodzi ludzie zaczynają się wyzwalać spod autorytetów (głównie rodziców) i tworzyć własny obraz rzeczywistości. Jest to okres szczególnych kryzysów religijnych i moralnych rodzących wątpliwości, a często utratę wiary ${ }^{14}$.

Kryzysy uwarunkowane są różnymi czynnikami zwłaszcza środowiskowymi i osobowościowymi jednostki (inteligencja, emocjonalność, religijność przedkryzysowa, samodzielność myślenia i działania, refleksyjność). Ponadto znaczny wpływ na rozwój kryzysu może mieć przeżywanie własnej płciowości i erotyzmu, które stawiają przed młodymi ludźmi pewne wymagania i ograniczenia. W usprawiedliwieniu własnych zaniedbań religijnych młodzi ludzie przerzucaja swoją niechęć właśnie do zakazów na wiarę i religię ${ }^{15}$.

Znaczącym czynnikiem kryzysotwórczym jest atomizacja współczesnego życia. Ciągły pośpiech, pęd, technicyzacja, ograniczają czas na przemyślenie własnego życia, jego celu i sensu, jak również swojej relacji do Boga. Prowadzi to nierzadko do nadużyć w sferze przeżyć zmysłowych oraz do szukania kompensacji w uzależnieniach (alkohol, narkotyki) ${ }^{16}$. Wpływa to w sposób znaczący na osłabienie wiary i pojawienie się kryzysu moralnego. Sprzyja mu nagłe odkrycie innego, fascynującego i pozornie lepszego systemu wartości, hipokryzja autorytetów, wejście w nowe środowisko, doświadczenie krzywdy lub zła, ocena dotychczasowej własnej moralności jako niewłaściwej itd.

Jednakże kryzysy moralne są szansą na zmianę pozytywną, uzależnioną znacznie od ukształtowanego genetycznie i środowiskowo sumienia. Za kryterium rozwoju sumienia Z. Chlewiński przyjmuje „rozwój psychiczny struktur poznawczo-oceniających, dzięki którym jednostka zna i uznaje za własne reguły moralne oraz rozwój odpowiednio z nimi sprzężonych reakcji emocjonalnych, ostrzegających przed naruszeniem reguł moralnych, karzących w przypadku popełnienia zła, bądź satysfakcjonujących w przypadku zrealizowania czynu do-

${ }^{14}$ Por. Cz. Walesa, Rozwój religijności człowieka, w: Z. Chlewiński (red.), Psychologia religii, Lublin 1982, s. 153-173; J. W. Fowler, Stages of Faith. The Psychology of Human Development and the Quest for Meaning, San Francisco 1981; F. Głód, Psychologiczna analiza kryzysów religijnych ludzi dorostych, w: K. Majdański (red.), Rozwój człowieka w modlitwie, Warszawa 1982, s. 53-54. Zob. Z. Trenti, L'esperienza religiosa, Torino 1999, s. 105-124.

${ }^{15}$ Por. W. Prężyna, Ksztaltowanie się życia religijnego, Znak 210/1971, s. 1575-1586; tenże, Symptomy dojrzałej religijności, w: W. Turek, J. Mariański (red.), Kościót w stużbie człowieka, Olsztyn 1997, s. 269-278.

${ }^{16}$ Por. H. Franta, Individualità e formazione integrale, Roma 1982; F. Bednarski, Wychowanie młodzieży dorastajacej, Roma 1976. 
brego" "17. W taki sposób sumienie staje się wykładnikiem wychowania, samowychowania i samooceny. Dzięki jego istnieniu człowiek może kontrolować własne zamierzenia i osiagnąć autonomię w swoich moralnych decyzjach ${ }^{18}$.

Czynnikiem warunkującym prawidłowy rozwój sumienia, wychowania moralnego i wychowania religijnego jest przede wszystkim oddziaływanie rodziny we wszystkich latach życia dziecka. W zależności od typologii rodziny ${ }^{19}$ (rodzina wzorowa, normalna, wydolna, niewydolna, patologiczna) może ona regulować podatność dziecka na wpływ środowiska zarówno negatywnie, jak i pozytywnie. Jednakże zróżnicowanie typów może wywoływać w młodszym wieku na samodzielną refleksję, chęć porównania, dążenia do lepszego życia, do niwelowania czynników hamujących wewnętrzny i zewnętrzny rozwój. Staje się przez to coraz bardziej świadomy konieczności dokonywania selekcji i wyborów, co ma ogromne znaczenie dla rozwoju osobistej autonomii ${ }^{20}$.

Pod wpływem uświadomienia sobie własnych (różnego typu) kompetencji młody człowiek nabiera poczucia współuczestniczenia w życiu i osobistej pełnowartościowości. Jest to bardzo istotne z punktu widzenia rozwoju dojrzałego sumienia, które w sposób bezpośredni wiąże się z dojrzałością do wychowania religijnego ${ }^{21}$.

Dużą rolę $\mathrm{w}$ formowaniu sumienia odgrywa budzenie u młodzieży świadomości, iż podlega ona różnym wpływom zewnętrznym (np. środowiska, mediów), manipulującym ich wyborami i przyjmowanymi postawami. Manipulacja ta wytwarza w świadomości swych odbiorców dwojakiego rodzaju efekty i przekonania. Po pierwsze, że rzeczywistość, np. moralna, jest taka, jaką im się przedstawia, i po drugie, że reakcja na tę rzeczywistość zależy od postawy samego człowieka, będącego w istocie obiektem manipulacji. Ważne jest, aby młody człowiek uświadomił sobie, na ile treści te wpływają na jego poglądy, przekonania czy sposoby wartościowania. Od tego bowiem zależy jego autonomia sumienia i niezależność myślenia ${ }^{22}$.

W wychowaniu zatem chodzi przede wszystkim o kształtowanie postaw odważnych, otwartych, autentycznych, niezależnych. Osiaganie takiej autonomii sprzyja wyzbywaniu się lęków, różnicowaniu wartości, przeżywaniu własnej wewnętrznej wolności, która ściśle wiąże się z odpowiedzialnością za rozwój własnej osobowości wiernej swoim przekonaniom.

W wychowaniu moralnym i kształtowaniu dojrzałej religijności najistotniejszą sprawą staje się więc nauka dokonywania własnych wyborów i właściwego

${ }^{17}$ Z. Chlewiński, Dojrzałość..., s. 74.

${ }^{18}$ Por. G. Allport, Osobowość i religia, Warszawa 1988, s. 58-64.

${ }^{19}$ Por. S. Kawula, Próba pedagogicznej typologizacji rodzin, w: S. Kawula, J. Bragiel, A. Janke (red.), Pedagogika rodziny, Toruń 1997, s. 153-174.

${ }^{20}$ B. Hołyst, System wartości i zdrowie psychiczne, Warszawa 1990, s. 14.

${ }^{21}$ Por. C. Fiore, Etica per giovani. Appunti e spunti per una educazione morale, Torino 1998.

${ }^{22}$ Por. Z. Chlewinski, Dojrzałość..., s. 89-107. 
moralnego oceniania oraz odkrywania prawdziwych wartości. Umiejętność ta może mieć duże znaczenie w rozwiązywaniu kryzysów religijnych, które niekoniecznie muszą kończyć się zobojętnieniem religijnym.

Wychowanie religijne, które wydaje się być podstawą w pokonywaniu wszelkich trudności, powinno być ukierunkowane na rozwój następujących czynników:

a) autonomii motywacji religijnej,

b) antropomorficznej koncepcji Boga,

c) umiejętności rozróżniania elementów istotnych w religii i przypadkowo z nią związanych,

d) umiejętności rozwiązywania kryzysów religijnych,

e) autentyczności przekonań religijnych.

Ad. a) Motywy postępowania człowieka nie zawsze są uświadomione i rozpoznane. Dojrzała motywacja czerpie początki z wczesnych doświadczeń, choć nie musi z nich wynikać. Motywacja religijna, będąc autonomiczną, jest przejawem dojrzałej religijności, która nie może być jednak mechanizmem obronnym. Wówczas bowiem nie jest dojrzała. Chodzi tu przede wszystkim o kształtowanie takiej motywacji, która wskazuje na wartości religijne będące istotą dla nich samych, a nie jako ucieczka przed lękiem, beznadziejnością czy załamaniem.

Ad. b) Nierzadko dorosły człowiek tworzy sobie fałszywy obraz Boga, zależny od jego możliwości intelektualno-moralnych. Tymczasem w wychowaniu religijnym chodzi o stworzenie obrazu Boga prawdziwego i transcendentnego, obrazu ponad wszelkimi pojęciami i wyobrażeniami. Dzięki refleksji możliwa jest korekcja swego myślenia, a tym samym kształtowanie dojrzałego obrazu Boga.

Ad. c) Bardzo ważna jest też umiejętność odróżniania w religii jej elementów istotnych i przypadkowych. Dotyczy to przede wszystkim moralnych zobowiązań człowieka religijnego.

Ad. d) Rozwój religijności związany jest oczywiście z kryzysami. Sposoby ich pokonywania mogą okazywać się twórcze i wpływać pozytywnie na jednostkę. Uczy się ona wówczas poznawać siebie, nazywać problemy, zwracać się do innych o pomoc.

Ad. e) Przekonania religijne dotyczą przede wszystkim rzeczywistości transcendentnej. Chodzi tu o osiagnięcie świadomości, że wiara wiąże się głównie z decyzją pełną zaufania, akceptującą system wartości, motywujący do działania. Przyjęcie prawd religijnych musi być świadome, przemyślane, zrozumiane i poddane wewnętrznej ocenie ${ }^{23}$.

Powyższe rozważania pozwalają na sformułowanie wniosku, że dojrzałość religijna osiągana w procesie wychowania odgrywa niepoślednią rolę w rozwoju jednostki i w ostatecznym efekcie prowadzi do wszechstronnego jej spełnienia i dojrzałej osobowości.

${ }^{23}$ Tamże. Por. K. Popielski, Doświadczenie sensu i jego znaczenie dla egzystencji, w: tenże (red.), Człowiek-wartości-sens. Studia z psychologii egzystencji, Lublin 1996, s. 55-60. 
W istocie dwie sfery: religijność i osobowość wzajemnie się warunkują w swoim dynamicznym rozwoju. Religijność wpływa na zakres i strukturę, integrację wartości, które z kolei modyfikują i ukierunkowują osobowość. Ta natomiast wzmacnia $\mathrm{w}$ jednostce poczucie godności i rodzi zaufanie do własnych możliwości etycznych. $Z$ kolei predyspozycje osobowościowe w znacznym stopniu kształtują zjawisko religijności. Dojrzała i zintegrowana religijność zakłada zdrową i w pełni rozwiniętą, dobrze funkcjonującą osobowość człowieka ${ }^{24}$.

\section{Podsumowanie. Polska religijność i wychowanie religijne w dobie pluralizmu}

W ostatnich kilkunastu latach wykonano wiele badań, w świetle których Polskę, obok Irlandii, można zaliczyć do najbardziej religijnych krajów Europy ${ }^{25}$. Tę uprzywilejowaną pozycję zapewniliśmy sobie, uzyskując $\mathrm{w}$ większości przyjętych w badaniach wskaźników religijności, pierwsze miejsce. Dotyczyło to również wychowania religijnego, instytucjonalnego i w domu rodzinnym. Moglibyśmy być $\mathrm{z}$ tego faktu niezwykle usatysfakcjonowani, gdyby aktualnie dostępne metody badań i współczesny język nauki opisywałyby w prosty i przekonywujący sposób doświadczenie sacrum. Oznacza to, że nawet najbardziej rzetelne badania niewiele mówią o rzeczywistej religijności społeczeństwa, podobnie jak nasze przekonania religijne są o wiele bardziej złożone, niż wskazywałyby na to oficjalne deklaracje.

Opinie na temat polskiej religijności i wychowania religijnego są skrajne, zarówno wśród osób świeckich, jak i duchowieństwa. Przypomnijmy wypowiedzi zmarłego ks. profesora Józefa Tischnera: „Jestem przekonany, że wchodzimy dziś w Polsce w kryzys wiary, jaki nie miał sobie równego. Polski katolicyzm znalazł się w stanie trudnej do ukrycia depresji. Wynika ona z przekonania, że pogłębia się przepaść między Kościołem a biegiem spraw publicznych”26. Tischner charakteryzuje Kościół polski, jako Kościół „schorowanej wyobraźni” ze względu na jego partykularyzm a nie powszechność, jego ideologię religijna, a nie apostolskość, za to, że nie jest Kościołem łaski, a raczej Kościołem moralnych potępień ${ }^{27}$.

${ }^{24}$ Por. tenże, Rola religii $w$ funkcjonowaniu osobowości, w: tenże (red.), Psychologia religii, Lublin 1982; L. Feuerbach, Das Wesen der Religion, Heidelberg 1983; K. Popielski, Noetyczny wymiar osobowości. Psychologiczna analiza poczucia sensu życia, Lublin 1994, s. 128-140; D. Rumpf, Bildung und Religion, Hildesheim 1997, s. 85-83; T. Borowska, Pedagogia ograniczeń ludzkiej egzystencji, Warszawa 1998, s. 41-60.

${ }^{25}$ Zob. P. M. Zulehner, H. Denz, Wie Europa lebt und Glaubt. Europäische Wertestudie, Düsseldorf 1993. s. 16-25; J. Mariański, Religijność spoleczeństwa polskiego w perspektywie europejskiej. Próba syntezy socjologicznej, Kraków 2004.

${ }^{26}$ J. Tischner, W krainie schorowanej wyobraźni, Znak 1997, nr 1 (500) s. 205.

${ }^{27}$ Tamże, s. 207. 
W dużej mierze bierze się to z niedostatku właśnie wychowania religijnego w domu rodzinnym oraz z indywidualnej i selektywnej religijności. Oznacza to, że wybieramy sobie dowolne przykazania do przestrzegania, prawdy do wierzenia i w konsekwencji nie czujemy się dostatecznie odpowiedzialni za siebie i innych. Nasza wiedza bardziej manifestuje się w praktykowaniu zwyczajów i obrzędów religijnych, związanych ze świętami, które nabierają często cech pogańskich ${ }^{28}$.

Zdaniem współczesnych socjologów i pedagogów społecznych, katolicyzm polski zakorzeniony jest bardziej w warstwie obyczajowo-kulturowej, niż w samej wierze. Sprzężony silnie z polską kulturą jest raczej znakiem przynależności do wspólnoty narodowej. Ów katolicyzm „,nawykowy” wyraźnie oddziela odświętne uczestnictwo w praktykach religijnych od zasad, jakimi Polacy kierują się w życiu codziennym ${ }^{29}$. Postawa taka powoduje rodzaj schizofrenii społecznej, charakterystycznej właśnie dla społeczeństwa w dobie pluralizmu, jak również dla epoki przejścia między tradycją a ponowoczesnością.

W takiej sytuacji polskie społeczeństwo, a zwłaszcza polska młodzież wymagają, używając słów zmarłego papieża Jana Pawła II, gruntownej, nowej ewangelizacji zwróconej w naszej polskiej rzeczywistości ku wartościom ewangelicznym, wartościom wobec Chrystusa i jego Kościoła ${ }^{30}$.

Przestrzenią, na której głównie manifestuje się religia jako sfera sacrum jest naturalnie Kościół instytucjonalny, ale wychowanie religijne realizuje się także $\mathrm{w}$ rodzinie $\mathrm{z}$ racji przysługującego rodzicom prawa naturalnego i w szkole, jako instytucji działającej in loco parentis. Z tych też względów dom rodzinny i szkoła należą nadal do podstawowych instytucji wychowawczych, w tym także wychowania religijnego. Chcąc sprostać wyzwaniom współczesnego pluralizmu, powinny one poszukiwać spójności aksjologicznej i metodologicznej, a w zakresie kształtowania zachowań religijnych, bardziej wspólnotowego i bardziej funkcjonalnego modelu życia. Niezależnie bowiem od kryzysu, jaki dostrzega się na gruncie polskiej religijności i w wychowaniu religijnym, to ono pozostaje w swych skutkach prawdziwym faktem pedagogicznej dojrzałości wychowawców.

Jak próbowałem dowieść w powyższym tekście, wychowanie religijne realizuje najpełniej rozwój osobowy człowieka, połączony z pozytywną koncepcją jego wolności i z określonym wyobrażeniem dobra. Współczesna szkoła zatem, w swej działalności wychowawczej nie może pomijać wartości, mających swe źródło w religii i przynależnych do sfery sacrum, niezależnie od pluralizmu światopoglądowego. Bowiem to nie sankcje zawarte implicite w normach społecznych i przepisach prawa, ale religijny i moralny nakaz sumienia, lub jeśli

${ }^{28}$ Por. J. Mariański, Kościół ludowy w poszukiwaniu nowej tożsamości społecznej, Znak 1997, $\operatorname{nr} 1$ (500), s. 41.

${ }^{29}$ E. Wnuk-Lipiński, Nadmierne nadzieje, nadmierne obawy. Czy integracja Europy zagraża Kościołowi?, Tygodnik Powszechny 1996, nr 4.

${ }^{30}$ Przestanie Jana Pawła II do Konferencji Episkopatu Polski ,,Wspólnota jest owocem wiary”, Tygodnik Powszechny 1997, nr 25. 
kto woli przymus wewnętrzny jest pewniejszą, choć wcale nie łatwiejszą drogą do respektowania podstawowych zasad moralnych ${ }^{31}$. Warto przypomnieć, że już w latach międzywojennych Sergiusz Hessen dostrzegał w wychowaniu religijnym i w głosie sumienia jedyną drogę do uzyskania przez jednostkę autonomii moralnej. Mówił: „Wychowanie wymaga przede wszystkim osobistego i wolnego udziału wychowanka w duchowych wartościach i dlatego nie może istnieć bez swobodnego wysiłku osobistego sumienia wychowanka"32. O istocie wychowania rozstrzyga bowiem samowychowanie się jednostki ludzkiej, dążącej do tego, by stać się autonomiczną osobowością ${ }^{33}$.

\section{Religious education in epoch of postmodernity (Summary)}

The author of the article presents the variants of new understanding of religious education in epoch of postmodernity. He tries to do it from historical and contemporary perspective, indicating false and unjustified alternative thinking about religion and education as a person's development. In the article religious education is defined as education going out from a person and orientated towards a person, that means that a person as an individual is a central moment of educational process. In author's opinion, religious education understood in such a way gives an opportunity for a person's integral development.

The article proves that religious education realizes individual person's development joint with positive conception of person's freedom and with specific idea of good in the most complete way. No doubt these are factors not only conditioning the possibility of defining person's own identity but also enabling to overcome postmodern ambivalence of reality that surrounds contemporary person.

${ }^{31}$ Por. W. Flitner, J. Derbolav, Problemi di etica pedagogica, Brescia 1988; J. Mariański, Religia i Kościót w społeczeństwie pluralistycznym, Lublin 1995.

32 S. Hessen, Poglad na świat a pedagogika, Kultura i Wychowanie 193/1933 s. 131; S. Rosik, Sumienie między wolnościq a prawdq, w: J. Nagórny, A. Deredziuk (red.), Człowiek-sumienie - wartości, Lublin 1997, s. 103-120.

${ }^{33}$ Por. tamże; W. Pannenberg, Antropologia in prospettiva teologica, Brescia 1997. 